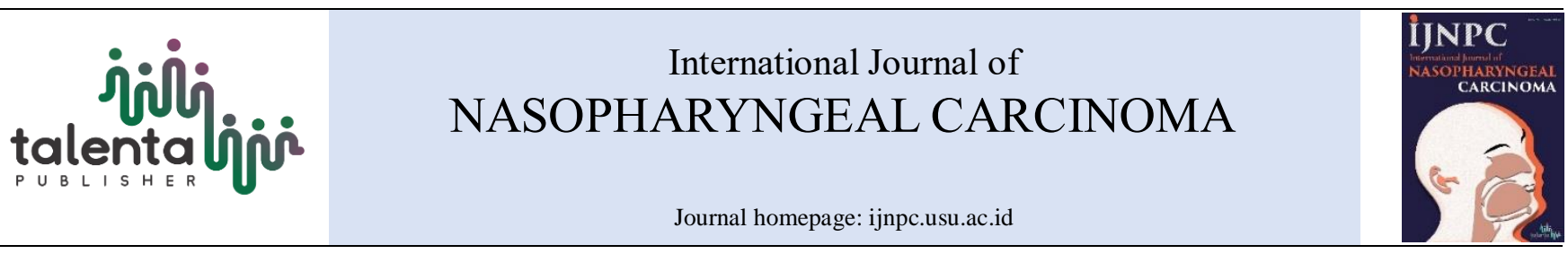

\title{
CHARACTERISTICS AND RISK FACTORS OF PATIENTS WITH NASOPHARYNGEAL CARCINOMA IN WEST NUSA TENGGARA HOSPITAL
}

\author{
Mochammad Alfian Sulaksana ${ }^{1 *}$, Hamsu Kadriyan ${ }^{1}$ \\ ${ }^{I}$ Departement of ENT HNS West Nusa Tenggara Hospital/Medical Faculty Mataram University
}

\begin{abstract}
Introduction: Nasopharyngeal carcinoma (NPC) is the most common cancer in the head and neck. NPC is a malignancy of squamous cell on nasopharyngeal epithelial with the most common predilection site in rosenmuller fossa. The etiology of this disease are multifactorial. A low oral hygiene on naso-orohypopharyngeal/laryngeal wall, Epstein Barr Virus (EBV) infection, smoking, alcohol consumption, genetic/hereditary factors, exposure to radiation, nutritional, deficiencies or decreased immune system are recognized as a risk factors. The study aim is to find out a characteristic of patients with nasopharyngeal carcinoma and their risk factors in the west Nusa Tenggara Hospital in September-October 2018.

Methods: The study design was descriptive-cross sectional. The research subjects were NPC patients who came to the West Nusa Tenggara Hospital ENT-HNS Clinic, in the period September-October 2018.

Results: There were 37 patients enrolled to this study. According to this study, the most patients found in age group 46 to 55 years $(35.1 \%)$, predominantly men $(67.6 \%)$ with the men and women ratio 2.5 : 1 . Based on patients origin, they come from all districts in west Nusa Tenggara province, with the most districts found in West Lombok $(29.7 \%$ ). The most risk factors were food factors (food preservative $19.9 \%$, food flavoring $19.9 \%$, salted fish $15.6 \%$ carcinogenic (grilled food) $6.5 \%$ ), and environmental factors (cigarettes $11.3 \%$, smoke $4.8 \%$ and $4.8 \%$ dust).

Conclusion: There were several risk factors found in this study, however, the most risk factor was food factors (61.9\%) followed by environmental factors $(20.9 \%)$.
\end{abstract}

\section{Article Info}

Keywords:

Nasopharyngeal carcinoma, risk factors, West Nusa Tenggara

\section{*Corresponding author}

Address: Universitas Mataram, Jl. Majapahit No.62, Gomong, Kec. Selaparang, Kota Mataram, Nusa Tenggara Bar. 83126

e-mail: dr.alfian.s@gmail.com

\section{INTRODUCTION}

Nasopharyngeal carcinoma (NPC) is the most common cancer in the head and neck area followed by thyroid cancer, laryngeal cancer and oropharyngeal cancer, with an incidence nearly $60 \%$ of overall neck head cancer [1]. NPC is a squamous cell malignancy on nasopharyngeal epithelial with the most common predilection site on rosenmuller fossa. NPC belong to the top five malignancies after cervical cancer, breast cancer, lymph nodes, and skin [2]. NPC can occur at any age, but patients rarely under the age of 20 years and the highest age between 45-54 years. Predominantly in men than women with a ratio between $2.4(2-3): 1[1,3,4]$.

The exact etiology of this disease is not yet known. There are several factors may interrelated, furthermore, it is concluded that the etiology of this disease is multifactorial. Low oral hygiene on the naso-oro-hypopharyngeal/laryngeal wall, and especially Epstein Barr Virus (EBV) infection shown in many NPC studies with a high increase in anti EBV titers, smoking, alcohol consumption, genetic/hereditary factors, exposure to radiation, nutritional deficiencies as well as decreased imune system (stamina) $[1,5,6]$.

Recent data reporting the causes of NPC is remain unknown, only state a number of risk factors (presdiposition) that are thought to be responsible for the occurrence of NPC, included: $[1,7]$

a. In traditional southern Chinese food, including salted fish (salted fish including salmon), piekled food (containing N-nitrosamine), and herbal chinese medicine.

b. Low socio-economic conditions, environment and life habits. It was said that smoke-filled air in poorly ventilated homes in China, Indonesia and Kenya increased the number of NPC cases. In Hong Kong, incense burning of houses is also considered to play a role in generating NPC.

c. Exposure to substances that are considered carcinogens, substances that can cause cancer, and chronic irritation such as exposure to cigarette smoke, incense, insect repellent, burning trash, vehicle gas disposal, fume, exposure to wood/plastic, factory dust, or exposure chemicals (formaldehyte, N-nitrosamine, benzopyrene, hydrocarbons) d. Genetic/Race, heredity and genetic vulnerability. Higher NPC incidence was found in Mongoloid offspring than in other races, although NPC was not included as a genetic tumor but susceptibility to NPC had familial aggregation. In most Asia, there are Chinese, both their home countries and overseas. Malay races namely Malaysia and Indonesia are among the most affected. Correlation analysis shows that the Human Leukocyte Antigen (HLA) gene and the gene encoding the cytochrome p4502E (CYP2E1) enzyme are likely to be susceptibility to NPC genes associated with most NPCs.

e. EBV virus infection which is activated by food-related ligmin macromolecule and spice mixture in southern China and Tunizia.

f. Chronic inflammation in the nasopharynx area. Considered in the presence of inflammation, the nasopharyngeal mucosa becomes more susceptible to environmental carcinogens.

The study aim was to find out the characteristics of patients with nasopharyngeal carcinoma and their risk factors in the West Nusa Tenggara Hospital from September-October 2018.

\section{MATERIAL AND METHODS}

The research subjects were all NPC patients who came to the West Nusa Tenggara Hospital ENT-HNS Clinic, in the period September-October 2018 and agree as subject of this research. This study was descriptive cross sectional. All data are collected, then organized into tables and figures based on age, sex, place of residence, and risk factors for NPC.

\section{RESULT}

During one and a half months of the study there were 37 patients fulfil the inclusion and exclusion criteria. According to the age, most of research subjects, aged were between 46 years to 55 years (35.10\%) (Table 1). The youngest age was 8 years and the oldest was 70 years. Distribution based on the gender, found that the cases was predominantly male (67.6\%) compared to women $(32.4 \%)$ (Table 2$)$. 
Table 1. Distribution of patients based on age group

\begin{tabular}{lcc}
\hline \multicolumn{1}{c}{ Age group (years) } & Number of cases & Percent (\%) \\
\hline Under 20 & 2 & 5.5 \\
$21-45$ & 11 & 29.7 \\
$46-55$ & 13 & 35.1 \\
Up to 56 & 11 & 29.7 \\
\hline Total & $\mathbf{3 7}$ & $\mathbf{1 0 0}$ \\
\hline
\end{tabular}

Table 2. Distribution of patients based on gender

\begin{tabular}{lcc}
\hline \multicolumn{1}{c}{ Gender } & Number of cases & Percent (\%) \\
\hline Man & 25 & 67.6 \\
Women & 12 & 32.4 \\
\hline Total & $\mathbf{3 7}$ & $\mathbf{1 0 0}$ \\
\hline
\end{tabular}

Distribution based on the area of residence, the patient came fromall districts in West Nusa Tenggara province. The most patients originated from West Lombok (29.7\%), and followed by East Lombok (16.2\%) and Mataram city (13.6\%). A detailed data are shown on table 3 .

Table 3. Distribution of patients based on demographics

\begin{tabular}{lcc}
\hline \multicolumn{1}{c}{ District/City } & Number of cases & Percent (\%) \\
\hline West Lombok & 11 & 29.7 \\
Central Lombok & 3 & 8.1 \\
East Lombok & 6 & 16.2 \\
Sumbawa & 4 & 10.8 \\
Dompu & 0 & 0 \\
Bima & 0 & 0 \\
West Sumbawa & 1 & 2.7 \\
North Lombok & 4 & 10.8 \\
Mataramcity & 5 & 13.6 \\
Bima city & 3 & 8.1 \\
\hline Total & $\mathbf{3 7}$ & $\mathbf{1 0 0}$ \\
\hline
\end{tabular}

According to the risk factors, there were several factors found in this study. The most risk factors were food factors (food preservative 19.9\%, food flavoring 19.9\%, salted fish 15.6\% carcinogenic (grilled food) $6.5 \%$ ), and environmental factors (cigarettes $11.3 \%$, smoke $4.8 \%$ and $4.8 \%$ dust).

Table 4. Distribution of patients based on risk factors for NPC

\begin{tabular}{lcc}
\hline \multicolumn{1}{c}{ Risk Factors } & Number of cases & Percent (\%) \\
\hline Food: & 115 & $61.8 \%$ \\
Salted fish & 29 & $15.6 \%$ \\
Food preservative & 37 & $19.9 \%$ \\
Food flavoring & 37 & $19.9 \%$ \\
Carcinogenic & 12 & $6.5 \%$ \\
(grilledfood) & & \\
Work: & 31 & $16.7 \%$ \\
$\quad$ Farmer & 13 & $7.0 \%$ \\
Factory & 10 & $5.4 \%$ \\
Fisherman & 8 & $4.3 \%$ \\
Genetics & 1 & $0.5 \%$ \\
Environment: & 39 & $21.0 \%$ \\
$\quad$ Exposure to smoke & 9 & $4.8 \%$ \\
$\quad$ Dust exposure & 9 & $4.8 \%$ \\
$\quad$ Cigarettes & 21 & $11.2 \%$ \\
\hline Total & $\mathbf{1 8 6}$ & $\mathbf{1 0 0 \%}$ \\
\hline
\end{tabular}

\section{DISCUSSION}

This study shows that the most NPC cases were found at the age group 4555 years old and predominantly men than women. The age of diagnosis obtained in this study is similar as in China, the NPC cases is increases after the age of 20 years and decreases after the age of 40 years, and average aged between 40 and 50 years $[2,7-9]$. This is also coherent with the research that has been conducted for 5 years (2002-2006) at RSUP Dr. Kariadi Semarang, which was found the most common age range for NPC, between $40-49$ years old with a percentage of $25.9 \%$ [7]. Based on the gender distribution found that the number of male respondents was greater than female respondents with a ratio of $2.5: 1$. This result was consistent with many previous studies who reported that NPC was more common in men than women, with a ratio of 2-3: $1[2,7,9]$.

The distribution of patients based on the demographics were found mostly in the area of West Lombok Regency, with the total cases was 11 or $29.7 \%$. This happen may due to the location of this area is in the coastal area and the number of industrial of wood and furniture factory is higher than other district. It may increase the risk factor for the NPC [10-13]. Based on a study by Chang and Adami (2006) [9], geographic site and races have a correlation with the NPC cases. May be this pattern was similar with West Nusa Tenggara, the cases is predominant in certain district. However, a further analysis should be done to answer this problem.
Several risk factors were investigated in this research such as food, occupational, genetic and environmental risk factors. According to our result, shows that food and environmental factors have a higher percentage than employment and genetics. This is coherent with the literature which states that occupational exposure to fume, smoke, dust or other chemicals such as pesticides increases the risk of nasopharyngeal carcinoma 2 to 6 times $[10,12,14-16]$. According to a case control study in Singapore, the consumption of weakly salted fish has the risk for NPC about $2.33(0.6$ $9.02)$ compared to $1.67(0.93-2.99)$ if the consumption only monthly. Consuming the smoked fish weekly was also a risk factors for NPC with the odd ratio $1.33(0.33-5.96)$ [17]. On the other research, found that salted fish consumption not significantly related to NPC, however the wood exposure correlated significantly [11].

Stimulation and inflammation of the chronic airway, reduced the mucocilliary clearance. This process will result in the changes of epithelial cells. After the accumulation of wood dust in the nasopharynx for a certain time will triggers the incidence of NPC. Exposure to wood solvents and preservatives, such as chlorophenol will also triggers the case of NPC. The presence of cigarette smoke as a risk factor for NPC clearly explained because cigarette smoke contains more than four thousand mixed materials and based on chemical analysis there are at least fifty types of carcinogens, one of them is tar. Carcinogens in inhaled cigarette smoke can induce nasopharyngeal mucosa directly $[12,15,18-20]$. Study in West Java, Indonesia, found that smoking is the most higher risk factors $(50.7 \%)$ followed by the used of mosquito coil and consumption of salted fish as much as $43.2 \%$ and $39.7 \%$ consecutively [16]. Passive smoker has higher ratio to suffer NPC compared to active smoker with the odd ratio 2.05 and 1.30 sequentially [15].

According to the above explanation, the risk factors for NPC remain debatable. However, it is logic that food factors and environmental factors should be considered although the occurrence of NPC involved the complex risk factors. A future research with a better design should be address to make sure the relationship between a certain risk factors on NPC. The knowledge about the risk factors is very important on prevention of this malignancy.

\section{CONCLUSION}

There were several risk factors found in this study, however, the most risk factor was food factors $(61.9 \%)$ followed by environmental factors $(20.9 \%)$.

\section{REFERENCE}

[1] Prabowo. I, Hendrik, editors. Kanker (Carcinoma) Nasofaring. In: Kanker Nasofaring Hendrik.H, Sumarwati, editor. . 1st ed ed: Uns Press; 2017.

[2] Adham M, Kurniawan AN, Muhtadi AI, Roezin A, Hermani B, Gondhowiardjo S, et al. Nasopharyngeal carcinoma in Indonesia: epidemiology, incidence, signs, and symptoms at presentation. 2012;31(4):185.

[3] Wei WJH, Williams NS-OtL, Wilkins. Nasopharyngeal Cancer in: Bailey, BJ, and Johnson, JT. 2006:1658-71.

[4] Ekburanawat W, Ekpanyaskul C, Brennan P, Kanka C, Tepsuwan K, Temiyastith $\mathrm{S}$, et al. Evaluation of non-viral risk factors for nasopharyngeal carcinoma in Thailand: results from a case-control study. 2010;11(4):929-32.

[5] Arditawati Y, Prasetyo A. Analisis hubungan antara faktor risiko dengan tipe histopatologik pada karsinoma nasofaring: Faculty of Medicine; 2011.

[6] Ondrey F, Wright SJBsoh, Decker nsPB. Neoplasms of the nasopharynx. 2006

[7] Prasetyo AJKklbdpadRDKt. Wiratno. 2002;2006.

[8] Zeng M-S, Zeng Y-X. Pathogenesis and etiology of nasopharyngeal carcinoma. Nasopharyngeal Cancer: Springer; 2010. p. 9-25.

[9] Chang ET, Adami H-OJCE, Biomarkers P. The enigmatic epidemiology of nasopharyngeal carcinoma. 2006;15(10):1765-77.

[10] Guo X, Johnson RC, Deng H, Liao J, Guan L, Nelson GW, et al. Evaluation of nonviral risk factors for nasopharyngeal carcinoma in a high - risk population of Southern China. 2009;124(12):2942-7.

[11] Yang XR, Diehl S, Pfeiffer R, Chen C-J, Hsu W-L, Dosemeci M, et al. Evaluation of risk factors for nasopharyngeal carcinoma in high-risk nasopharyngeal carcinoma families in Taiwan. 2005;14(4):900-5.

[12] Hsu W-L, Chen J-Y, Chien Y-C, Liu M-Y, You S-L, Hsu M-M, et al. Independent effect of EBV and cigarette smoking on nasopharyngeal carcinoma: a 20-year follow-up study on 9,622 males without family history in Taiwan. 2009;18(4):1218-26. 
[13] Simons MJJCjoc. Nasopharyngeal carcinoma as a paradigm of cancer genetics. 2011;30(2):79.

[14] Mimi CY, Yuan J-M, editors. Epidemiology of nasopharyngeal carcinoma. Seminars in cancer biology; 2002: Elsevier.

[15] Yuan JM, Wang XL, Xiang YB, Gao YT, Ross RK, Yu MCJIjoc. Non - dietary risk factors for nasopharyngeal carcinoma in Shanghai, China. 2000;85(3):364-9.

[16] Hardianti RA, YAD, editors. Risk factor of nasopharyngeal carcinoma in Dr. Hasan Sadikin General Hospital Bandung. 1st National Conference of Nasopharyngeal Carcinoma; 2018: USU press.

[17] Yong SK, Ha TC, Yeo MCR, Gaborieau V, McKay JD, Wee J. Association of lifestyle and diet with the risk of nasopharyngeal carcinoma in Singapore: a case-control study.2017;36(3):1-8.

[18] Indrasari SR, C H, editors. Methods of NPC early detection and screening in Indonesia. 1st National Conference of Nasopharyngeal Carcinoma; 2018: USU press.

[19] Feng B, Khyatti M, Ben-Ayoub W, Dahmoul S, Ayad M, Maachi F, et al. Cannabis, tobacco and domestic fumes intake are associated with nasopharyngeal carcinoma in North Africa. 2009;101(7):1207.

[20] Lee Y-CA, Boffetta P, Sturgis EM, Wei Q, Zhang Z-F, Muscat J, et al. Involuntary smoking and head and neck cancer risk: pooled analysis in the International Head and Neck Cancer Epidemiology Consortium. 2008;17(8):1974-81. 